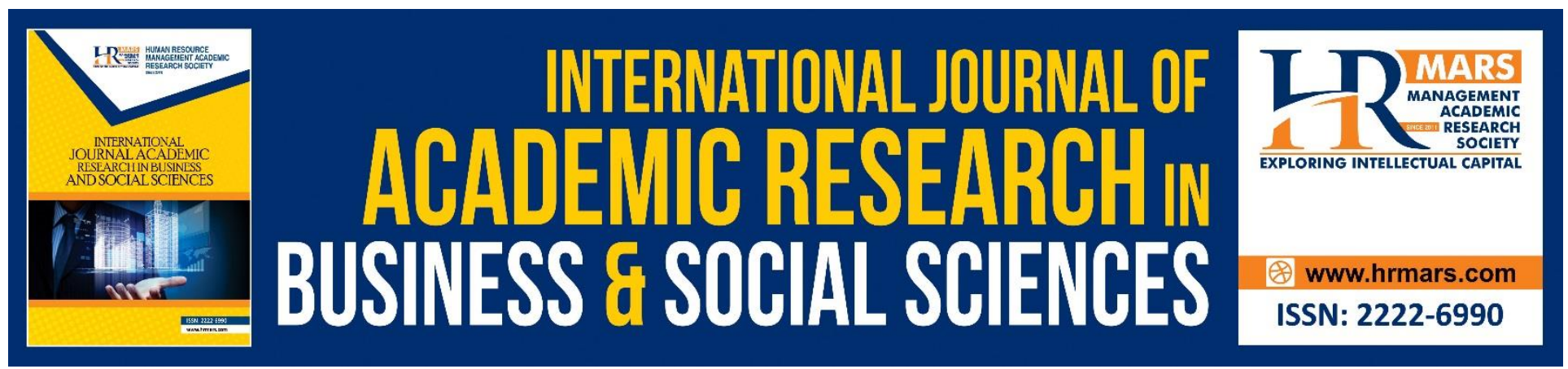

\title{
The Cause of Non-Performing Loan in Retail and Commercial Working Capital (Case of Bank XYZ in Province Nanggroe Aceh Darussalam)
}

Muhamad Abdul Haris \& Dwinita Aryani

To Link this Article: http://dx.doi.org/10.6007/IJARBSS/v8-i12/5043

DOI: 10.6007/IJARBSS/v8-i12/5043

Received: 14 Nov 2018, Revised: 13 Dec 2018, Accepted: 25 Dec 2018

Published Online: 26 Dec 2018

In-Text Citation: (Haris \& Aryani, 2018)

To Cite this Article: Haris, M. A., \& Aryani, D. (2018). The Cause of Non-Performing Loan in Retail and Commercial Working Capital (Case of Bank XYZ in Province Nanggroe Aceh Darussalam). International Journal of Academic Research in Business and Social Sciences, 8(12), 437-448.

Copyright: (c) 2018 The Author(s)

Published by Human Resource Management Academic Research Society (www.hrmars.com)

This article is published under the Creative Commons Attribution (CC BY 4.0) license. Anyone may reproduce, distribute, translate and create derivative works of this article (for both commercial and non-commercial purposes), subject to full attribution to the original publication and authors. The full terms of this license may be seen at: http://creativecommons.org/licences/by/4.0/legalcode

Vol. 8, No. 12, 2018, Pg. 437 - 448

Full Terms \& Conditions of access and use can be found at http://hrmars.com/index.php/pages/detail/publication-ethics 


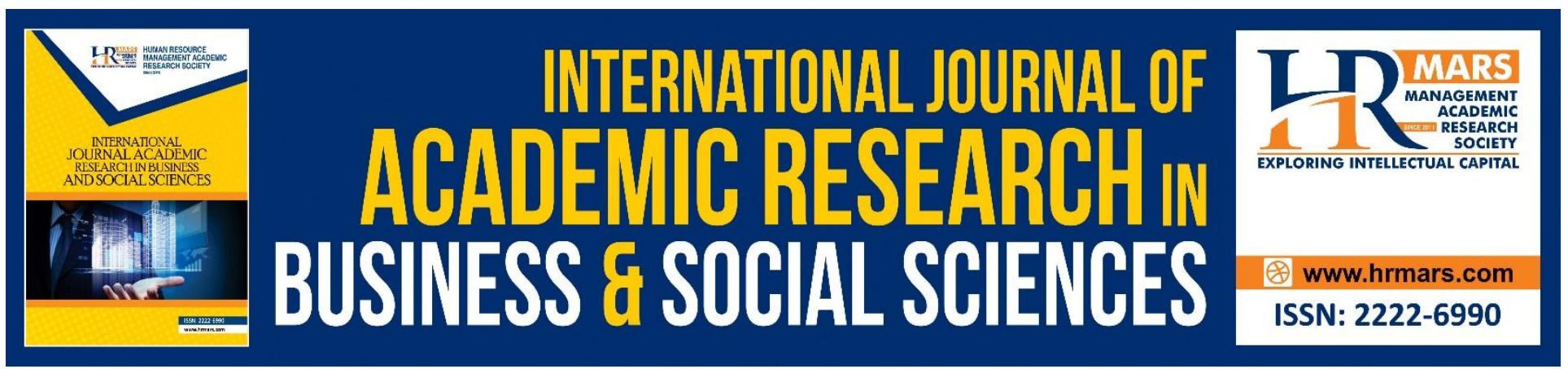

\title{
The Cause of Non-Performing Loan in Retail and Commercial Working Capital (Case of Bank XYZ in Province Nanggroe Aceh Darussalam)
}

\author{
Muhamad Abdul Haris \& Dwinita Aryani \\ STIE Malangkucecwara, Malang, Indonesia
}

Abstract: The purpose of this research is to study and analyze the determinant factors of nonperforming loan in retail and commercial working capital commercial banks' interest margin in Province Nanggroe Aceh Darussalam (NAD) Indonesia. This study extends the literature on the determinants of NPL through investigating whether banks XYZ in NAD anticipate non-performing loans by provide information about the factors that cause non-performing loans and how alternatives are resolved. This study implies in broaden knowledge and share the experiences of researchers as practitioners in the banking sector and as a comparison between theoretical concepts and the existing reality conditions as a result of research.

Keywords: Non-Performing Loan, Banking and Credit, Indonesian Banking

\section{Introduction}

The banking sector has a strategic role in the economy of a country; with commercial banks is one of the economic actors who have a vital role. As financial intermediation function performed by banks, having a good performance is a must in which it has an impact on the economic growth and economy stability of a country (Raharjo, Hakim, Manurung, \& Maulana, 2014). In the case of credit expansion process, must use the principle of prudence in running its business, the aim is to maintain the quality of credit. If only a non-performing loan existing in a bank, there will be dangerous impact to the bank itself. Credit according to Indonesian law No. 10 of 1998 Chapter I, article 1 (11), namely:

Credit is the provision of money or bills that can be likened to it based on an agreement or loan agreement between banks and other parties which requires the borrower to repay the debt after a certain period of time with interest.

The risks faced by banks related to lending are the possibility of non-performing loans even until the credit becomes a write-off that is caused by various factors. The basis of sound non-performing loans management is the identification of the existing and potential risks inherent in lending activities. An uncollectable account receivable is a loss of revenue that requires, through proper entry in the accounts, a decrease in the asset accounts receivable and a related decrease in income and 
INTERNATIONAL JOURNAL OF ACADEMIC RESEARCH IN BUSINESS AND SOCIAL SCIENCES

Vol. 8, No. 12, Dec, 2018, E-ISSN: 2222-6990 @ 2018 HRMARS

stockholders' equity. Non-performing loans in banking terms are better known as NPL (Non Performing Loans). NPL is an indicator in assessing the health of bank assets. One form of credit risk according to Dendawijaya ( 2003) is a non performing loans (NPL), because if there is a lot of nonperforming loans will be very detrimental to the bank itself. This indicator is a principal financial ratio that can provide information on the condition of capital assessment, profitability, credit risk, and market risk and bank liquidity. This NPL or non-performing loans has an impact on reducing bank capital (Breuer, 2006). If this is allowed, it will have an impact on lending in the next period.

However, there is a need to proceed from prior studies to investigate how banks anticipate NPLs, particularly, by making some balance sheet adjustments. Because the size of NPLs among banks in some developing countries appear too minimized. Overall, the significance and predictive power of each bank-specific factor (excluding loan diversification. NPL reflects credit risk, the higher the level of NPL, the greater the credit risk borne by the bank (Jorda, Schularick, \& Taylor, 2013). The size of the bank's NPL shows an indication of credit problems in the bank (Louzis, Vouldis, \& Metaxas, 2012). The amount of credit based on its usage and the number of NPLs from 2010 to 2017 in the table of selected economic indicators sourced from publication data through the official website of Bank Indonesia (www.bi.go.id/publikasi/kajian-ekonomi-regional/aceh) appears in table 1 as follows:

Table 1

Credit based on bank usage

Province of Nanggroe Aceh Darussalam, period 2010 to 2017 (In millions)

\begin{tabular}{|c|c|c|c|c|c|c|}
\hline & \multicolumn{3}{|c|}{ Credit } & \multicolumn{2}{c|}{ NPL } \\
\hline Year & $\begin{array}{c}\text { Working } \\
\text { capital }\end{array}$ & Consumption & Investment & Amount & $\%$ & IDR \\
\hline 2010 & 6.091 .199 & 8.668 .804 & 998.142 & 15.758 .145 & $4,88 \%$ & 768.997 \\
\hline 2011 & 6.336 .779 & 10.980 .864 & 1.069 .609 & 18.387 .252 & $4,16 \%$ & 764.714 \\
\hline 2012 & 6.626 .366 & 10.431 .835 & 999.456 & 18.057 .657 & $4,63 \%$ & 835.680 \\
\hline 2013 & 7.251 .596 & 11.433 .558 & 1.893 .797 & 20.578 .951 & $4,40 \%$ & 905.316 \\
\hline 2014 & 7.197 .526 & 12.424 .383 & 2.322 .772 & 21.944 .681 & $4,38 \%$ & 964.247 \\
\hline 2015 & 8.040 .000 & 16.080 .000 & 3.100 .000 & 27.220 .000 & $3,64 \%$ & 990.000 \\
\hline 2016 & 8.840 .000 & 17.300 .000 & 3.810 .000 & 29.950 .000 & $2,64 \%$ & 790.000 \\
\hline 2017 & 10.130 .000 & 19.240 .000 & 3.790 .000 & 33.160 .000 & $1,90 \%$ & 630.000 \\
\hline
\end{tabular}

(Source: LBU Bank Indonesia)

With the background of the above data, the growth of credit expansion is quite positive and prudent, and balanced by a significant decrease in NPLs, as evidenced by the 2010 NPLs which were $4.88 \%$ down to $1.90 \%$ at the end of 2017. This shows an effort controlling and decreasing non-performing loans of conventional commercial banks in the province of Nanggroe Aceh Darussalam is very serious.

\section{Problem Formulation}

Based on the description above, the formulation of the problem is: "How are the process of credit distribution and the process of anticipating non-performing loans in commercial retail working capital study-cases at PT. Bank XYZ in Nanggroe Aceh Darussalam Province?" 
INTERNATIONAL JOURNAL OF ACADEMIC RESEARCH IN BUSINESS AND SOCIAL SCIENCES

Vol. 8, No. 12, Dec, 2018, E-ISSN: 2222-6990 C 2018 HRMARS

\section{Research Objectives}

1. Analyze the process of commercial retail working capital loan distribution

2. Analyzing the causes and anticipation of non-performing loans and alternative solutions to commercial retail working capital loans (a case study at PT. Bank XYZ in Nanggroe Aceh Darussalam Province).

The next section presents the theoretical framework and summaries of some relevant previous research.

\section{Literature Review \\ Bank}

Definition of banks according to law No. 7 of 1992 concerning banking as amended by law No. 10 of 1998, "Banks are business entities that collect funds from the public in the form of deposits and channel them to the public in order to improve the standard of living of the people according to Riyadi, (2004).

Definition of credit according to banking law number 10 of 1998:

Credit is the provision of money or bills that can be likened to it, based on a loan agreement between banks and other parties that requires the borrower to repay the debt after a certain period of time with interest.

With regard to banking products, several banking principles are recognized in banking law, namely the fiduciary relation principle, the prudential principle, the secrecy principle, the know how customer principle and the principle of recognizing employee (know how your employee).

In the credit appraisal process, credit officials in general according to Riyadi (2004) use the principles of credit assessment called $6^{\prime} \mathrm{C}$ as follows:

1. Character, an assessment based on the goodwill of prospective debtors.

2. Capacity, an assessment that is based on the willingness of the customer to pay off the obligations and the interest.

3. Capital, an assessment based on the capital or wealth owned by prospective customers.

4. Collateral, an assessment based on goods or collateral that is submitted by the debtor as collateral for the loan received.

5. Condition, an assessment based on the company's environmental conditions.

6. Constrains, assessments that are based on the possibility of the emergence of predictable obstacles.

The criteria for a quality credit or not size is based on its collectability. The purpose of determining credit collectability is to determine credit quality so that banks can anticipate credit risk early because credit risk can affect the business continuity of the bank(Riyadi, 2004; Siamat, 2005). In accordance with the provisions of PBI No.14 / 15 / PBI / 2012 and SE BI No.7 / 3 / DPN, credit quality can be determined based on the following three parameters: business prospects, debtor performance and debtor's ability to pay.

Based on these parameters, credit quality is determined to be 5 (five) collectability, namely Current (Col.1); In Special Mention (Coll.2); Substandard (Coll.3); Doubtful (Coll.4) and Loss (Coll.5). 
Non-performing loans (NPL) in Indonesia

NPLs or non-performing loans are one indicator of the health of bank assets. This indicator is a principal financial ratio that can provide information on the condition of capital assessment, profitability, credit risk, market risk and liquidation. The NPL used is the net NPL, the NPL that has been adjusted. Assessment of asset quality is an assessment of the condition of bank assets and the adequacy of credit risk management.

Non-performing loans according to Dendawijaya (2003) is a condition where customers are unable to pay part or all of their obligations to the bank as agreed. According toRiyadi (2004), The ratio of non-performing loans is the ratio between the amount of credit given to the level of collectability which is a non-performing loan compared to the total credit given by the bank. Non-performing loans also reflect the credit risk that occurs in the bank. Meanwhile, according to Siamat (2005)Nonperforming loans are non-current loans or loans where the debtor does not meet the agreed conditions such as interest payment requirements, interest loan principal withdrawals, increased margin deposits, binding and increasing collateral, and so on. The non-performing loan (NPL) ratio or collectability level achieved reflects the effectiveness and efficiency of the implementation of the crediting strategy.

Grouping on the quality of bank credit needs to be done so that the quality of the bank's earning assets can be observed, so that the risk of inhibition of the bank's productive assets can be reduced. According to Bank Indonesia regulation No. 7/2 / PBI / 2005 concerning the assessment of the quality of commercial bank assets article 10, in determining the quality of credit, banks must pay attention to factors of business prospects, performance and ability to pay debtors. Bank Indonesia has determined a non-performing loan (NPL) of 5\%.

While non-performing loans are caused by external non-bank and debtor factors, namely a decrease in the country's monetary conditions and the existence of government regulations and other restrictive regulations that have a major impact on the financial and operational situation of the bank (Suryanto, 2015), the influence of inflation and exchange rates(Alexandri \& Santoso, 2015). Whereas according to Alexandri \& Santoso, (2015)external factors can basically be incorporated into conditions. Included in these external factors are business competition, business conditions and natural factors.

Table 2

Classification of credit quality

\begin{tabular}{|c|l|l|}
\hline Collectability & Explanation & Delinquency (day) \\
\hline 1 & Current & 0 \\
\hline 2 & $\begin{array}{l}\text { Special } \\
\text { attention }\end{array}$ & 1 day to 90 days \\
\hline 3 & Substandard & 91 days to 120 days \\
\hline 4 & Doubtful & $\begin{array}{l}121 \text { days s/d 180 } \\
\text { days }\end{array}$ \\
\hline 5 & Loss & More than 180 days \\
\hline
\end{tabular}

(Source: Kuncoro and Suhardjono, 2002) 
According to Ozili (2015), the process of providing and managing good credit is expected to reduce the NPL as small as possible. In other words, the high NPL is strongly influenced by the bank's ability to carry out the loan process well and in terms of credit management, including monitoring actions after the credit has been channeled and control measures if there are indications of credit irregularities or indications of default. Considering the condition and status of a bank's NPL in principle, it is based on the timeliness of the customer to pay the obligation, either in the form of interest payments or repayment of principal.

\section{Previous Research}

The empirical literature on the Non-Performing Loan is vast and diverse. In context of Indonesia, previous summary findings are presented below.

a. Poetry \& Sanrego, (2011) finds that NPF in Islamic banking is more stable than NPL in conventional banking to deal with macro and micro variables fluctuation. According to FEVD variables affecting NPL in conventional banking are inflation and SBI.

b. Study of Sari (2012) show that the principle of prudence in lending policy is the principle $5 \mathrm{C}$ consisting of: Character, Capacity, Capital, Collateral, Condition. Furthermore, result of regression analysis showed a significant effect of the non- performing loans to the loanto-deposit ratio.

c. Artini, Setiawina, \& Djayastra, (2015) result show that credit grant was positively and significantly affected by internal and external condition of the LPD, and the condition of the LPD's debtor's candidate. While the credit grant itself was released to be negatively and significantly affected the NPL of the LPD in Gianyar Regency.

d. The findings of Dwihandayani (2017) study revealed that the performance of banking NPLs in Indonesia in 2012 to 2016 is still quite well below 5\%. Overall, in 2016 NPLs of banks almost increased except Bank BRI. The effect of the variables on the NPL is sequentially given credit, inflation, LDR, LAR and $B I$ rate, with the classical test results also concluded that NPLs with LDR, LAR, inflation, BI rate, and credit provided have a strong correlation.

\section{Methodology}

This type of research is research that uses descriptive methods, which can be interpreted as a problem-solving procedure that is investigated by describing the state of the subject or object in the research can be in the form of people, institutions, communities and others that are currently based on facts that appear as it is.

The research data is based on the report on problem loans specifically for working capital loans (KMK) for commercial retail branches of PT. Bank XYZ which was established in 1978 in the province of Nanggroe Aceh Darussalam for the reporting period of 2010 to 2017. There are two categories of data which consist of:

a. Primary data, conduct interviews with $X Y Z$ bank employees and their customers.

b. Secondary data, information and information obtained from agencies or agencies related to this research. 
INTERNATIONAL JOURNAL OF ACADEMIC RESEARCH IN BUSINESS AND SOCIAL SCIENCES Vol. 8, No. 12, Dec, 2018, E-ISSN: 2222-6990 C 2018 HRMARS

The subject of this study was the branch office of PT. Bank XYZ in the Province of Nanggroe Aceh Darussalam with informants from the researchers themselves and employees of the XYZ bank. This research used interview and literature study as method to collect data. Using a qualitative descriptive method that is analyzingdata by interviewing the bank in the form of sentences and descriptions that relate theories that are relevant to the problem under study. According to previous authors(Riyadi, 2004; Siamat, 2005), the NPL ratio was formulated as follows: NPL $=$ Problematic loan $\times 100 \%$

Total loan

Assessment criteria based on NPL component ratings can be seen in table 3:

Table 3

NPL component ranking matrix

\begin{tabular}{|c|c|c|}
\hline Non Performing Loans & Risk Value & Risk Predicate \\
\hline$\leq 10 \%$ & 1 & Very good \\
\hline $10 \%<\mathrm{NPL} \leq 15 \%$ & 2 & Good \\
\hline $15 \%<\mathrm{NPL} \leq 20 \%$ & 3 & Pass \\
\hline $20 \%<\mathrm{NPL} \leq 25 \%$ & 4 & Bad \\
\hline $25 \%<\mathrm{NPL}$ & 5 & Very bad \\
\hline
\end{tabular}

(Source: SE BI No.13 / 1 / PBI / 2011)

The smaller NPL value will led to smaller the credit risk borne by the bank. Banks in conducting credit must analyze the ability of the debtor to repay their obligations. After the credit is given, the bank must monitor the use of credit and the ability and compliance of the debtor in fulfilling its obligations. The Bank undertakes a review and binding of collateral to minimize credit risk.

Table 4

Comparison of Pure NPL vs. NPL due to irregularities in the use of KMK Bank XYZ commercial retail credit, 2010 to 2017

(IDR millions)

\begin{tabular}{|c|c|c|c|c|c|c|c|c|}
\hline \multirow{3}{*}{ Year } & \multicolumn{4}{|c|}{ Pure KMK NPL } & \multicolumn{4}{|c|}{ NPL Due to KMK Deviations } \\
\hline & \multicolumn{3}{|c|}{ Collectability } & \multirow{2}{*}{$\begin{array}{l}\text { Amount } \\
\text { IDR }\end{array}$} & \multicolumn{3}{|c|}{ Collectability } & \multirow{2}{*}{$\begin{array}{l}\text { Amount } \\
\text { IDR }\end{array}$} \\
\hline & 3 & 4 & 5 & & 3 & 4 & 5 & \\
\hline 2010 & 862 & 1.104 & 1.483 & 3.449 & 1.913 & 1.407 & 2.307 & 5.628 \\
\hline 2011 & 872 & 1.214 & 1.027 & 3.113 & 1.527 & 1.279 & 1.320 & 4.126 \\
\hline 2012 & 1.272 & 1.232 & 1.470 & 3.974 & 2.459 & 1.715 & 1.544 & 5.718 \\
\hline 2013 & 1.339 & 1.686 & 1.933 & 4.958 & 1.212 & 2.787 & 2.060 & 6.059 \\
\hline 2014 & 1.705 & 1.979 & 1.814 & 5.498 & 1.385 & 2.624 & 3.280 & 7.289 \\
\hline 2015 & 1.626 & 1.429 & 1.872 & 4.927 & 1.772 & 2.697 & 3.236 & 7.706 \\
\hline 2016 & 1.772 & 1.962 & 2.595 & 6.329 & 1.146 & 1.696 & 1.742 & 4.583 \\
\hline 2017 & 1.915 & 1.451 & 2.437 & 5.803 & 1.821 & 1.928 & 1.607 & 5.357 \\
\hline
\end{tabular}


INTERNATIONAL JOURNAL OF ACADEMIC RESEARCH IN BUSINESS AND SOCIAL SCIENCES

Vol. 8, No. 12, Dec, 2018, E-ISSN: 2222-6990 C 2018 HRMARS

\section{Result and Discussion}

\section{General description of the bank}

Bank XYZ has: 1 head office in Jakarta, established in 1895, has branch offices throughout Indonesia and also several countries. One branch of the XYZ bank which is the object of this research is in the province of Nanggroe Aceh Darussalam, established in 1978. Bank XYZ serves medium credit (loans more than $2 \mathrm{M}$ to $35 \mathrm{M}$ ), people's business loans, government program loans, consumer credit (employees and retirees) and micro-credit.

Table 5

PT Bank XYZ's commercial retail loan portfolio

Year 2010 to 2017 (IDR millions)

\begin{tabular}{|c|c|c|c|c|c|c|c|}
\hline \multirow[t]{3}{*}{ Year } & \multicolumn{7}{|c|}{ Commercial Retail Loans } \\
\hline & \multirow{2}{*}{$\begin{array}{c}\text { Working } \\
\text { Capital } \\
\text { IDR }\end{array}$} & \multirow{2}{*}{$\begin{array}{c}\text { Investment } \\
\text { IDR }\end{array}$} & \multirow{2}{*}{$\begin{array}{c}\text { Amount } \\
\text { IDR }\end{array}$} & \multicolumn{2}{|c|}{ Performing Loans } & \multicolumn{2}{|c|}{$\begin{array}{c}\text { Non Performing } \\
\text { Loans }\end{array}$} \\
\hline & & & & IDR & $\%$ & IDR & $\%$ \\
\hline 2010 & 237,26 & 67,34 & 304,60 & 295,53 & $97,02 \%$ & 9,077 & $2,98 \%$ \\
\hline 2011 & 259,71 & 78,54 & 338,25 & 331,01 & $97,86 \%$ & 7,239 & $2,14 \%$ \\
\hline 2012 & 282,54 & 85,98 & 368,52 & 358,83 & $97,37 \%$ & 9,692 & $2,63 \%$ \\
\hline 2013 & 309,18 & 95,85 & 405,03 & 394,01 & $97,28 \%$ & 11,017 & $2,72 \%$ \\
\hline 2014 & 332,61 & 106,81 & 439,42 & 426,63 & $97,09 \%$ & 12,787 & $2,91 \%$ \\
\hline 2015 & 349,87 & 111,16 & 461,03 & 448,40 & $97,26 \%$ & 12,632 & $2,74 \%$ \\
\hline 2016 & 361,36 & 121,51 & 482,87 & 471,96 & $97,74 \%$ & 10,913 & $2,26 \%$ \\
\hline 2017 & 381,52 & 130,38 & 511,90 & 500,74 & $97,82 \%$ & 11,159 & $2,18 \%$ \\
\hline
\end{tabular}

Source: Bank XYZ

Based on the data in table 5 above, special problem loans on commercial retail working capital loans (KMK) are still in the fair category, still below $3 \%$ on average by $2.57 \%$ per annum, greater than the overall average NPL the loans at the XYZ branch office are around 1.91\% per year. However, it is necessary to further examine the causes of fluctuations in the rise of the KMK NPL.

Viewed from the internal side of the bank, this was due to:

1) Account officer builders rarely visit debtors, considering the ratio or the number of debtors who have paid too much (average $1 \mathrm{AO}$ has 60 to 75 accounts)

2) The distance and geographical condition of the customer's location are quite far from the city center, with a distance of 2 hours to 4 hours from the branch office to the customer.

3) The ratio between the numbers of Account Officers is not proportional regarding to the number of debtors / customers.

4) Orientation among $\mathrm{AO}$ focuses on credit expansion to achieve year-end targets.

\section{Analysis of the causes of problem loans}

The causes of non-performing loans of PT Bank XYZ's commercial retail KMK are as follows: 
1) Internal factors of the bank include: account officer (AO) who concurrently functions as a marketing with the function as a credit analyst; Less prudent credit breakers before deciding credit and management policies related to the settlement of non-performing loans need to be evaluated.

2) Debtor factors:

a. The pure NKK NPL causes are due to business risk or because the risks are directly related to the debtor's business, while:

b. NPL of KMK due to irregularities or misuse of KMK funds by debtors for consumptive and speculative purposes and not directly related to a bank-financed business.

\section{Rescue of non-performing loans}

The effort to implement credit restructuring at $X Y Z$ bank for rescue was carried out for all collectability with the aim of adjusting the debtor's repayment ability and the installment amount so that its collectability would be smooth (collectability 1). Collectability of performance loan (PL) is for collectability 1 and 2 .

Restructuring credit for non-performing loans (collectability 3, 4 and 5): that is by doing $3 R$ restructuring and using a combination of restructuring: Rescheduling, Reconditioning and Restructuring. Taking into account the rescue of credit adjusted to the willingness and ability to pay the debtor. Because there are changes in both changes in credit terms; changes in the time period and / or decrease in loan interest rates.

\section{Completion of problem loans}

PT. Bank XYZ in completing the problem loans as follows:

a) Peacefully through: Billing with a persuasive approach; Conduct notation or renewal of debts for both notation subjects and objects; Sale of collateral assets (collateral) on a voluntary basis from collateral owner customers. This is in accordance with Artini et al., (2015); Poetry \& Sanrego, (2011); and Sari, (2012). If the credit analysis is good and according to the business conditions, the occurrence of non-performing loans can be minimized from the beginning.

b) The legal route is carried out by executing collateral / collateral assets or auctions, especially debtors that are included in the Regional Office, taking into account their economic and security aspects. This is in accordance with the results of research with Sari (2012)where the character and ability factors with adequate collateral are the priority.

In practice, Bank XYZ has tried to apply the principles of prudential banking, especially in conducting credit analysis 6'C (Character, Capacity, Capital, Collateral, Condition of economic and Constrains) in processing prospective debtor credit according to the theory presented by Riyadi (2004). Included also in terms of determining credit quality based on parameters: Business prospects; Debtor performance and ability to pay, in accordance with Bank Indonesia regulations.

\section{Conclusion}

The degree of success of a bank greatly depends on the ability of management to ensure that the practice of risk management mitigates the impact of non performing loans that existed. One set of policies include those aimed to limit or reduce credit risk, such as policies on concentration and 
adequate diversification, large exposure, or lending to connected parties. It is truly worthy to pointed out to the fact that non performing loans are major intents of banking business. Furthermore, the emergence of non-performing loans cannot be avoided by a banking financial institution, but the most important is how bank management makes efforts as a preventive and anticipatory step to minimize the possibility of credit becoming problematic in the future. The early prevention efforts as a concrete manifestation of preventive and anticipatory measures that must be carried out by the bank include:

1) Screening customer characters more selectively.

2) All credit application processes must be in accordance with the appropriate system and procedures.

3) The target of credit expansion must be realistic in accordance with developments and conditions of local economic growth,

4) The quality of the mental attitude of $A O$ candidates must be of high quality and integrity.

5) Development of performance support technology and monitoring of credit must be available and always up to date.

Early detection and self-recognition will be very important to anticipate possible problems that arise, both individually and in the credit portfolio and plan and take steps before the problem actually occurs. The cause of non-performing loans in this study was caused by internal factors of the bank, among others, the account officer credit initiator (AO); credit breaker and credit administration section. This study has limitations that can lead to less than optimal results of the research, which is only limited to commercial retail KMK and data samples only from 2010 to 2017.

\section{Suggestion}

The management and credit personnel should have favorable moral ethics, professional knowledge, experience, skills, and positive attitude to solve problems suitably and analyze and judge the strategic location and credit business correctly. Good credit starts from good customer selection and mental attitude and sharp and objective credit analysis capabilities in accordance with the conditions and prospects of the debtor's business and supported by experience and ability to predict credit breakers before the credit is approved to be disbursed. If only a problematic condition of credit occurs, there is an alternative solution to the settlement of a peaceful (win-win solution).

Internal bank factors that need attention include Account officer (AO), which they bleed to improve the quality of $\mathrm{AO}$ competencies in terms of credit analysis. Also, AO must always monitor debtor loan account transactions at any time, so that the probability of deterioration in collectability can be predicted. Thus, AO must be objective and brave in terms of the need to "restructure" credit with current collectability and special attention, if it is necessary. The percentage increase in the target of new credit expansion is not too large; it must be realistic by looking at the conditions of local economic growth. AO credit proponents for new customers remain responsible until the credit is paid off. By using the Global Positioning System (GPS) by AO will help to have more prudential banking when determine the location of the collateral and the place of business and domicile of the debtor with clearly marked boundaries.

For decision credit officers, especially in the extension of credit, the credit officer can immediately instruct the AO to carry out credit restructuring if it sees the extended business conditions and 
prospects of the customer not in accordance with the cash flow. They need to do "Parate execution" to provide a deterrent effect on debtors on will. This will implies for management or head office in bank $X Y Z$ that is necessary to review the ratio of $A O$ to debtors, so that the productivity of AOs in carrying out coaching and monitoring of debtors can be carried out optimally. Thus, bank XYZ must have policy for credit extension, at least 2 (two) months before the credit is due, so that the credit extension has been done by $\mathrm{AO}$ and is ready to be given a decision (Extended or restructured). In the customer's credit analysis process, it is better to do it with the AO team (minimum three AO or more), in which the aim is to minimize the $A O$ subjectivity in providing credit recommendations if it is done by an AO collegially collective. Credit decisions at branch offices are carried out by committees involved in credit officers, AOs and credit administration officers. It is necessary to do a "switching account" between AOs in managing accounts or debtors must be done every 2 years. The application of an "early warning system" system in monitoring collectability based on the maturity date, whether the interest payments and or credit principal can be monitored every day and every time. Several practical suggestion presented below:

a. Data collection and mapping are regularly needed for bad credit collateral.

b. Determination of a "certain time limit" in the case of settlement of non-performing loans.

c. Bank management cooperates with relevant agencies to resolve non-performing loans.

This study was further limited due to generalising the study as it only focus on commercial banks $X Y Z$ in one province. Thus the study only focused on commercial banks limiting the finding to commercial banks. A further study should be carried to investigate the relationship between management practices for non performing loans and level of non performing loans for the commercial banks in bigger areas.

\section{Acknowledgment}

The authors of this article declare no conflict of interest. The authors are responsible for the content and writing of the paper.

\section{Corresponding Author \\ Muhamad Abdul Haris}

Corresponding Author.

Email: samharis97@gmail.com

STIE Malangkucecwara Malang

Jl. Terusan Candi Kalasan, Blimbing, Mojolangu, Lowokwaru, Kota Malang, Jawa Timur 65142 Indonesia.

\section{References}

Alexandri, M. B., \& Santoso, T. I. (2015). Non Performing Loan : Impact of Internal and External Factor ( Evidence in Indonesia ). International Journal of Humanities and Social Science Invention, 4(1), 87-91.

Artini, R., Setiawina, N. D., \& Djayastra, K. (2015). Analisis Pengaruh Faktor Internal dan Eksternal Terhadap Jumlah Kredit dan Dampaknya Terhadap Non Performing Loan (NPL) pada Lembaga Perkreditan Desa (LPD) - Desa Adat di Kabupaten Gianyar. E-Jurnal Ekonomi Dan Bisnis 
INTERNATIONAL JOURNAL OF ACADEMIC RESEARCH IN BUSINESS AND SOCIAL SCIENCES

Vol. 8, No. 12, Dec, 2018, E-ISSN: 2222-6990 @ 2018 HRMARS

Universitas Udayana, 11(4), 867-894.

Breuer, J. B. (2006). Problem bank loans, conflicts of interest, and institutions. Journal of Financial Stability, 2, 266-285. https://doi.org/10.1016/j.jfs.2006.07.001

Dendawijaya, L. (2003). Manajemen Perbankan. Jakarta: Ghalia Indonesia.

Dwihandayani, D. (2017). Analisis Kinerja Non Performing Loan ( Npl ) Perbankan Di Indonesia Dan Faktor-Faktor Yang Mempengaruhi Npl. Jurnal Ekonomi Bisnis, 22(3), 265-274.

Jorda, O., Schularick, M., \& Taylor, A. (2013). When Credit Bites Back. Journal of Money, Credit and Banking, 45, 3-28.

Louzis, D. P., Vouldis, A. T., \& Metaxas, V. L. (2012). Macroeconomic and Bank-Specific Determinants of Non-Performing Loans in Greece: a Comparative Study of Mortgage, Business and Consumer Loan Portfolios. Journal of Banking \& Finance, 36(4), 1012-1027.

Ozili, P. K. (2015). How Bank Managers Anticipate Non-Performing Loans Evidence from Europe, US Asia and Africa. Applied Finance and Accounting, 1(2), 73-80. https://doi.org/10.11114/afa.v1i2.880

Poetry, Z. D., \& Sanrego, Y. D. (2011). Pengaruh variabel makro dan mikro terhadap NPL perbankan konvensional dan NPF perbankan syariah. Islamic Finance \& Business Review, Vol. 6(2), 79-104.

Raharjo, P. G., Hakim, D. B., Manurung, A. H., \& Maulana, T. N. A. (2014). The Determinant of Commercial Banks' Interest Margin in Indonesia : An Analysis of Fixed Effect Panel Regression. International Journal of Economics and Financial Issues, 4(2), 295-308.

Riyadi, S. (2004). Banking Assets and Liabilitiy Management. Jakarta: Penerbit Lembaga Penerbit Fakultas Ekonomi Universitas Indonesia.

Sari, N. F. dan R. L. (2012). Analisis Kebijakan Pemberian Kredit Dan Pengaruh Non Performing Loan Terhadap Loan To Deposit Ratio Pada Pt. Bank Rakyat Indonesia (Persero), Tbk Cabang Rantau, Aceh Tamiang. ( Periode 2007-2011). Jurnal Ekonomi Dan Keuangan, 1(1), 88-101.

Siamat, D. (2005). Manajemen Lembaga Keuangan. Kebijakan Moneter dan Perbankan (1st ed.). Jakarta: Lembaga Penerbit FEUI.

Suryanto. (2015). Non Performing Loans on Regional Development Bank in Indonesia and Factors that Influence. Mediterranean Journal of Social Sciences, 6(4), 280-287. https://doi.org/10.5901/mjss.2015.v6n4p280 